\title{
ANALISIS RASIO ARUS KAS UNTUK MENGUKUR KINERJA KEUANGAN PADA PT KALBE FARMA Tbk.
}

\author{
Meldawati, Febryandhie Ananda \\ STIE "KBP” Padang \\ (melda19@ymail.com) \\ (febryandhie.ananda@gmail.com)
}

\begin{abstract}
This study aims to determine how the use of analytical techniques in the current ratios measure the financial performance of PT Kalbe Farma Tbk. In this study the authors use secondary data from financial statements of PT Kalbe Farma Tbk for 5 years (2008-2012). The analytical method used is a form where the ratio of the value in the statement of financial position, statement of comprehensive income, statement of changes in equity and statement of cash flows into the simplified ratios. Data were analyzed using 8 cash flow ratio is the ratio of operating cash flow, cash flow coverage ratio, interest coverage ratio of the cash, the cash coverage ratio of current liabilities, capital expenditure ratio, the ratio of total debt, the ratio of net cash flow and free cash flow adequacy ratio. The results of this study indicate each cash flow ratios from 2008 to 2012 average ratio produced tends to be low and has decreased every year.
\end{abstract}

Keyword: Cash Flow Ratio, Financial Performance

\section{PENDAHULUAN}

Dalam PSAK No. 2 (Revisi 2009) dikatakan bahwa sebuah perusahaan pada awalnya bertujuan untuk mendapatkan keuntungan yang besar dengan melakukan strategi jitu untuk mencapai target yang diinginkan. Untuk dapat mencapai tujuan dan untuk mengetahui tingkat kinerjanya, setiap perusahaan harus menyajikan suatu laporan keuangan pada suatu periode. Untuk itu perusahaan harus mencermati dan menganalisis kinerja perusahaan, salah satunya melalui analisis dengan menggunakan laporan keuangan berupa laporan arus kas.

Seperti yang dijabarkan dalam Pernyataan Standar Akuntansi Keuangan No. 2 (Revisi 2009) laporan arus kas sebagai bagian yang tidak terpisahkan dari laporan keuangan perusahaan, menyajikan data mengenai kondisi kas perusahaan dari aktivitas operasi, investasi dan pendanaan. Laporan arus kas memiliki kandungan informasi yang bermanfaat dalam menentukan likuiditas dan fleksibilitas kinerja keuangan perusahaan yang bisa diperoleh melalui analisis laporan arus kas dengan menggunakan rasio - rasio arus kas.

Menurut Darsono dan Ashari di dalam bukunya "Pedoman Praktis Memahami Laporan Keuangan" (2005), semakin banyaknya perusahaan yang mencantumkan laporan arus kas dalam laporan keuangan tahunan, membuat penggunaan informasi 
laporan arus kas sebagai alat analisis kinerja keuangan perusahaan kian meningkat. Salah satu analisis kinerja keuangan adalah dengan menggunakan analisis rasio arus kas. Analisis kinerja keuangan perusahaan khususnya dengan menggunakan laporan arus kas perusahaan diharapkan dapat membantu perusahaan untuk menilai kemampuan perusahaan dalam membayar kewajiban lancar, membayar komitmen - komitmennya, membayar bunga atas hutang yang telah ada, membayar hutang lancar, mengukur modal yang tersedia untuk investasi dan pembayaran hutang, serta mengukur kemampuan perusahaan dalam memenuhi kewajiban kas dimasa datang guna pengambilan keputusan atau penyusunan kebijakan untuk masa yang akan datang demi terciptanya peningkatan hasil dari kinerja keuangan perusahaan.

\section{TINJAUAN PUSTAKA DAN HIPOTESIS}

Akuntansi merupakan suatu sistem informasi yang memberikan keterangan mengenai data ekonomi untuk pengambilan keputusan bagi siapa saja yang membutuhkannya. Dalam akuntansi informasi yang dimaksudkan itu disusun dalam ikhtisar dalam laporan keuangan.

Ada beberapa pengertian laporan keuangan menurut pendapat para ahli yang dapat Penulis gunakan sebagai bahan pertimbangan. Menurut Munawir (2004:2), "Laporan keuangan pada dasarnya adalah hasil dari proses akuntansi yang dapat digunakan sebagai alat untuk mengkomunikasikan data keuangan atau aktivitas suatu perusahaan". Menurut Soemarso (2010:368), "Laporan keuangan meliputi neraca, laporan laba rugi dan laba ditahan, laporan arus kas serta catatan atas laporan keuangan". Menurut Sofyan S. Harahap, dalam buku Analisa Kritis Atas Laporan Keuangan (2006:105), "Laporan keuangan adalah laporan yang menggambarkan kondisi keuangan dan hasil usaha suatu perusahaan pada saat tertentu atau jangka waktu tertentu". Sedangkan definisi laporan keuangan menurut PSAK No. 1 (Revisi 2009) tentang Penyajian Laporan Keuangan paragraf 9 (IAI, 2009:) adalah sebagai berikut: "Laporan keuangan adalah suatu penyajian terstruktur dari posisi keuangan dan kinerja keuangan suatu entitas."

Dari beberapa defenisi di atas, Penulis menyimpulkan bahwa pengertian laporan keuangan adalah laporan yang menggambarkan hasil dari proses akuntansi berupa penyajian terstruktur dari posisi keuangan dan kinerja keuangan suatu entitas sebagai sarana pengkomunikasian informasi keuangan kepada pihak - pihak yang berkepentingan.

Laporan keuangan pada hakekatnya merupakan hasil dari proses akuntansi yang terdiri dari transaksi transaksi dan peristiwa yang bersifat finansial dicatat, digolongkan, dan diringkaskan dengan cara yang tepat dalam satuan uang dan kemudian diadakan penafsiran untuk berbagai tujuan. Berbagai tindakan tersebut tidak lain merupakan seni pencatatan, penggolongan, peringkasan transaksi dan peristiwa yang bersifat finansial dalam cara yang tepat dan dalam bentuk rupiah, dan penafsiran akan hasilnya dapat digunakan untuk mengkomunikasikan data keuangan kepada pihak yang berkepentingan. Agar tidak salah dalam memakai informasi (laporan akuntansi) ini maka perlu diketahui secara benar pengertian dari proses akuntansi atau disebut juga siklus akuntansi. 


\section{Metode Analisis Laporan Keuangan}

Menurut Munawir (2004:36), secara umum metode analisis laporan keuangan dapat diklasifikasikan menjadi dua klasifikasi, yaitu:

a. Metode analisis horizontal (dinamis).

Metode analisis horizontal (dinamis) adalah metode analisis yang dilakukan dengan cara membandingkan laporan keuangan untuk beberapa periode, sehingga dapat diketahui perkembangan dan kecenderungannya. Disebut metode analisis dinamis karena metode ini bergerak dari tahun ke tahun (periode). Teknik teknik analisis yang termasuk pada klasifikasi metode ini adalah teknik analisis perbandingan, analisis trend (index), analisis sumber dan penggunaan dana, analisis perubahan laba kotor.

b. Metode analisis vertikal (statis). Metode analisis vertikal (statis) adalah metode analisis yang dilakukan dengan cara menganalisis laporan keuangan pada tahun (periode) tertentu, yaitu dengan membandingkan antara pos yang satu dengan pos lainnya pada laporan keuangan yang sama pada tahun (periode) yang sama. Oleh karena membandingkan antara pos yang satu dengan lainnya pada laporan keuangan yang sama, maka disebut metode vertikal. Disebut metode statis karena metode ini hanya membandingkan pos - pos laporan keuangan pada tahun (periode) yang sama. Teknik teknik analisis yang termasuk pada klasifikasi metode ini adalah teknik analisis persentase per komponen (common size), analisis rasio, dan analisis impas.

\section{Teknik Analisa Laporan Keuangan}

Menurut S. Munawir, teknik analisa yang biasa digunakan dalam analisa laporan keuangan adalah sebagai berikut :

1. Analisa perbandingan laporan keuangan

Merupakan metode dan teknik analisa dengan cara membandingkan laporan keuangan untuk dua periode atau lebih, dengan menunjukkan :

a. Data absolut atau jumlah dalam rupiah,

b. Kenaikan atau penurunan dalam jumlah rupiah,

c. Kenaikan atau penurunan dalam prosentase,

d. Perbandingan yang dinyatakan dalam rasio, dan

e. Prosentase dari total.

2. Trend atau tendensi posisi dan kemajuan keuangan perusahaan yang dinyatakan dalam prosentase, adalah suatu teknik analisa untuk mengetahui tendensi daripada keadaan keuangannya, apakah menunjukkan tendensi tetap, naik atau bahkan turun.

3. Laporan dengan prosentase per componen atau common size statement adalah suatu metode analisa untuk mengetahui prosentase investasi pada masing - masing aktiva terhadap total aktivanya, juga untuk mengetahui struktur permodalannya dan komposisi perongkosan yang terjadi dihubungkan dengan jumlah penjualannya. 
4. Analisa sumber dan penggunaan modal kerja adalah suatu analisa untuk mengetahui sumber sumber serta penggunaan modal kerja atau untuk mengetahui sebab - sebab berubahnya modal kerja dalam periode tertentu.

5. Analisa sumber dan penggunaan kas (Cash Flow Statement Analysis), adalah suatu analisa untuk mengetahui sebab - sebab berubahnya jumlah uang kas atau untuk mengetahui sumber sumber serta penggunaan uang kas selama periode tertentu.

6. Analisa ratio, adalah suatu metode analisa untuk mengetahui hubungan dari pos - pos tertentu dalam neraca atau laporan laba rugi secara individu atau kombinasi dari kedua laporan tersebut.

7. Analisa perubahan laba kotor (gross profit analysis), adalah suatu analisa untuk mengetahui sebab - sebab perubahan laba kotor suatu perusahaan dari periode ke periode yang lain atau perubahan laba kotor suatu periode dengan laba yang dibudgetkan untuk periode tersebut.

8. Analisa break-even, merupakan suatu analisa untuk menentukan tingkat penjualan yang harus dicapai oleh suatu perusahaan agar perusahaan tersebut tidak menderita kerugian, tetapi juga belum memperoleh keuntungan. Dengan analisa break-even ini akan diketahui berbagai tingkat keuntungan atau kerugian untuk berbagai tingkat penjualan.

\section{Laporan Arus Kas}

Untuk menjaga kelancaran operasi usahanya perusahaan memerlukan kas dan kas harus diatur secara seksama, agar tidak terlalu banyak atau terlalu sedikit yang tersedia setiap waktu.

\section{Klasifikasi Laporan Arus Kas}

Laporan arus kas (cash flows) diklasifikasikan menurut setiap arus kas masuk dan arus kas keluar ke dalam kategori aktivitas - aktivitas. Menurut PSAK 2 Revisi 2009 arus kas masuk dan arus kas keluar suatu perusahaan dalam satu periode dapat diklasifikasikan menjadi 3 kategori, yaitu :

1) Kas yang berasal dari atau digunakan untuk aktivitas operasi.

2) Kas yang berasal dari atau digunakan untuk aktivitas investasi.

3) Kas yang berasal dari atau digunakan untuk aktivitas pendanaan.

\section{Analisis Rasio Laporan Arus Kas}

Salah satu analisis kinerja keuangan dengan menggunakan informasi laporan arus kas adalah analisis rasio laporan arus kas. Analisis laporan arus kas ini menggunakan komponen dalam laporan arus kas dan komponen neraca dan laporan laba rugi sebagai informasi dalam analisis rasio.

Menurut Darsono dan Ashari di dalam bukunya "Pedoman Praktis Memahami Laporan Keuangan" (2005:91), alat analisis rasio laporan arus kas yang diperlukan untuk menilai kinerja keuangan perusahaan antara lain :

\section{Rasio Likuiditas Arus Kas}

1.1 Rasio Arus Kas Operasi (AKO) Rasio Arus Kas Operasi menghitung kemampuan arus kas operasi dalam membayar kewajiban lancar. 
Rasio ini diperoleh dengan membagi arus kas operasi dengan kewajiban lancar.

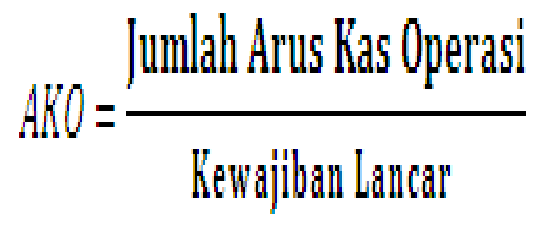

Keterangan:

$\mathrm{AKO}=$ Arus kas operasi

Rasio arus kas operasi yang berada dibawah 1 berarti terdapat kemungkinan perusahaan tidak mampu membayar kewajiban lancar, tanpa menggunakan arus kas dan aktivitas lain.

\subsection{Rasio Cakupan Arus Dana (CAD)}

Rasio ini digunakan untuk mengetahui kemampuan perusahaan dalam menghasilkan kas guna membayar komitmen komitmennya (bunga, pajak, dan dividen preferen).

$$
C A D=\frac{\text { BuIT }}{\text { Bunga }+ \text { Penyesuaian Pajak }+ \text { Deviden Preferen }}
$$

Keterangan:

CAD = Cakupan arus dana

EBIT = Earning Before

Interest and Tax

Rasio yang besar menunjukkan bahwa kemampuan yang lebih baik dari laba sebelum pajak dalam menutup komitmen komitmen yang jatuh tempo dalam satu tahun.

1.3 Rasio Cakupan Kas terhadap Bunga (CKB)

Rasio ini digunakan untuk mengetahui kemampuan perusahaan dalam membayar bunga atas hutang yang telah ada. Rasio ini diperoleh dengan arus kas dari operasi tambah pembayaran bunga dan pembayaran pajak dibagi pembayaran bunga.

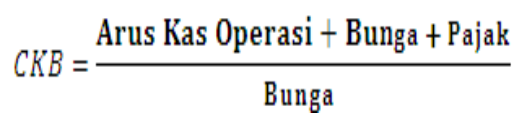

Keterangan:

$\mathrm{CKB}=$ Cakupan kas terhadap bunga

Dengan rasio yang besar menunjukkan bahwa arus kas operasi mempunyai kemampuan yang lebih baik dalam menutup biaya bunga sehingga kemungkinan perusahaan tidak mampu membayar bunga sangat kecil.

1.4 Rasio Cakupan Kas terhadap Hutang Lancar (CKHL)

Rasio ini mengukur kemampuan perusahaan dalam membayar hutang lancar berdasarkan arus kas operasi bersih. Rasio ini diperoleh dengan arus kas operasi ditambah dividen kas dibagi dengan hutang lancar.

$C K H L=\frac{\text { Arus Kas Operasi }+ \text { Deviden Kas }}{\text { Hutang Lancar }}$

Keterangan:

CKHL = Cakupan kas terhadap hutang lancar

Rasio yang rendah menunjukkan kemampuan yang rendah dari arus kas operasi dalam menutup hutang lancar.

1.5 Rasio Pengeluaran Modal (PM) Rasio ini digunakan untuk mengukur modal tersedia untuk investasi dan pembayaran hutang yang ada. Rasio ini diperoleh dengan arus kas operasi dibagi dengan pengeluaran modal.

$$
P M=\frac{\text { Arus Kas Operasi }}{\text { Pengeluaran Modal }}
$$

Keterangan:

$\mathrm{PM}=$ Pengeluaran modal 
Rasio yang tinggi menunjukkan kemampuan yang tinggi dari arus kas dalam membiayai pengeluaran modal.

\subsection{Rasio Total Hutang (TH)}

Rasio ini menunjukkan jangka waktu pembayaran hutang oleh perusahaan dengan asumsi semua arus kas operasi digunakan untuk membayar hutang. Dengan mengetahui rasio ini, kita bisa menganalisis dalam jangka waktu berapa lama perusahaan akan mampu membayar hutang dengan menggunakan arus kas yang dihasilkan dari aktivitas operasioanal perusahaan.

$$
T H=\frac{\text { Arus Kas Operasi }}{\text { Total Hutang }}
$$

Keterangan :

$\mathrm{TH}=$ Total hutang

Rasio yang cukup rendah menunjukkan bahwa perusahaan mempunyai kemampuan yang kurang baik dalam membayar semua kewajibannya dari arus kas yang berasal dari aktivitas normal operasi perusahaan.

2. Rasio Fleksibilitas Arus Kas

2.1Rasio Arus Kas Bersih Bebas (AKBB)

Rasio ini berguna untuk mengukur kemampuan perusahaan dalam memenuhi kewajiban kas dimasa mendatang.

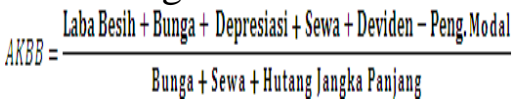

Keterangan :

$\mathrm{AKBB}=$ Arus kas bersih bebas

Peng. Modal = Pengeluaran modal
2.2 Rasio Kecukupan Arus Kas (KAK).

Rasio ini mengukur kemampuan perusahaan dalam menyediakan kas untuk memenuhi kewajibannya dalam jangka 5 tahun mendatang.

KAK $=\frac{\text { EBIT }- \text { Bunga }- \text { Pajak }- \text { Pengeluaran Modal }}{\text { Rata Rata hutang Lancar Selama Lima Tahun }}$

Keterangan :

KAK $=$ Kecukupan

arus kas

EBIT = Earning

Before Interest and Tax

Rasio yang rendah menunjukkan bahwa

kemampuan perusahaan yang rendah dalam menyediakan kas untuk memenuhi kewajibannya dalam jangka 5 tahun mendatang.

\section{Kinerja Keuangan}

Kinerja berasal dari kata performance, kinerja dinyatakan sebagai prestasi yang dicapai oleh perusahaan dalam suatu periode tertentu yang mencerminkan tingkat kesehatan dari perusahaan tersebut. Pengukuran kinerja adalah penentuan secara periodik tampilan perusahaan yang berupa kegiatan operasional, struktur organisasi, dan karyawan yang berdasarkan sasaran, standar dan kriteria yang telah ditetapkan sebelummya (Mulyadi, 2001:419; (Ananda, Putra and Hendrastyo, 2017; Ananda and Zulvia, 2018)).

Kinerja keuangan dapat dikatakan sebagai hasil yang dicapai oleh perusahaan atas berbagai aktivitas yang dilakukan dalam mendayagunakan sumber keuangan yang tersedia. Kinerja keuangan dapat dilihat dari análisis laporan keuangan atau analisis rasio keuangan. Menurut Arief Habib (2008:91) bahwa "Kinerja keuangan 
diukur dengan banyak indikator, salah satunya adalah análisis rasio keuangan" Untuk melakukan analisis rasio keuangan tersebut diperlukan perhitungan rasio - rasio keuangan yang mencerminkan aspek - aspek tertentu. Rasio keuangan diperoleh dengan cara menghubungkan dua atau lebih data keuangan.

\section{Tujuan Pengukuran Kinerja Keuangan}

Munawir (2004:31) menyatakan bahwa tujuan dari pengukuran kinerja keuangan perusahaan adalah :

1. Mengetahui tingkat likuiditas Likuiditas menunjukkan kemampuan suatu perusahaan untuk memenuhi kewajiban keuangan yang harus segera diselesaikan pada saat ditagih.

2. Mengetahui tingkat solvabilitas Menunjukkan kemampuan perusahaan untuk memenuhi kewajiban keuangannya apabila perusahaan tersebut dilikuidasi, baik keuangan jangka pendek maupun jangka panjang.
3. Mengetahui tingkat rentabilitas Rentabilitas atau yang sering disebut dengan profitabilitas menunjukkan kemampuan perusahaan untuk menghasilkan laba selama periode tertentu.

4. Mengetahui tingkat stabilitas/Fleksibilitas

Menunjukkan kemampuan perusahaan untuk melakukan usahanya dengan stabil, yang diukur dengan mempertimbangkan kemampuan perusahaan untuk membayar hutang-hutangnya serta membayar beban bunga atas hutang - hutangnya tepat pada waktunya.

Dengan demikian dapat disimpulkan bahwa pengukuran kinerja keuangan memberikan penilaian atas pengelolaan aset perusahaan oleh manajemen dan manajemen perusahaan dituntut untuk melakukan evaluasi dan tindakan perbaikan atas kinerja keuangan perusahaan yang tidak sehat.

Tabel 1

Tinjauan Penelitian Terdahulu

\begin{tabular}{|c|c|c|c|c|}
\hline No. & $\begin{array}{c}\text { Nama } \\
\text { Peneliti / } \\
\text { Tahun } \\
\end{array}$ & Judul Penelitian & Variabel & Hasil Penelitian \\
\hline 1. & $\begin{array}{l}\text { Hengky } \\
\text { Setiawan } \\
(2006)\end{array}$ & $\begin{array}{l}\text { Analisis Rasio Arus } \\
\text { Kas Pada Perusahaan } \\
\text { Kelompok Industri } \\
\text { Semen }\end{array}$ & $\begin{array}{l}\text { Independen: Analisis } \\
\text { Rasio Arus Kas } \\
\text { Dependen: Kinerja } \\
\text { Perusahaan }\end{array}$ & $\begin{array}{l}\text { PT. Semen Cibinong memiliki } \\
\text { aktivitas operasi yang kurang } \\
\text { efektif karena memiliki } \\
\text { kemampuan yang kurang baik } \\
\text { dalam membayar semua } \\
\text { kewajibannya dari arus kas } \\
\text { normal operasi perusahaan. } \\
\text { Analisis rasio arus kas pada PT. } \\
\text { Semen Gresik terjadinya } \\
\text { peningkatan terus menerus pada } \\
\text { setiap periodenya. Untuk PT } \\
\text { Indocement, analisis rasio arus } \\
\text { kas perusahaan ini menyatakan } \\
\text { bahwa perusahaan mampu } \\
\text { membayar kewajiban lancarnya } \\
\text { dengan arus kas operasinya. }\end{array}$ \\
\hline No. & $\begin{array}{c}\text { Nama } \\
\text { Peneliti / } \\
\text { Tahun }\end{array}$ & Judul Penelitian & Variabel & Hasil Penelitian \\
\hline
\end{tabular}




\begin{tabular}{|c|c|c|c|c|}
\hline 2. & $\begin{array}{l}\text { Difi } \\
\text { Handoko } \\
\text { (2010) }\end{array}$ & $\begin{array}{l}\text { Analisis Laporan Arus } \\
\text { Kas Sebagai Alat } \\
\text { Ukur Efektivitas } \\
\text { Kinerja Keuangan } \\
\text { Pada PT Perkebunan } \\
\text { Nusantara III } \\
\text { (Persero) Medan }\end{array}$ & $\begin{array}{l}\text { Independen : Analisis } \\
\text { Laporan Arus Kas } \\
\text { Dependen : Kinerja } \\
\text { Keuangan }\end{array}$ & $\begin{array}{l}\text { Berdasarkan hasil analisis rasio } \\
\text { arus kas pada PT Perkebunan } \\
\text { Nusantara III Medan } \\
\text { menyatakan bahwa perusahaan } \\
\text { memiliki rasio dengan nilai } \\
\text { yang rendah. Walaupun } \\
\text { demikian, arus kas dari aktivtas } \\
\text { operasi perusahaan mampu } \\
\text { memiliki kemampuan yang } \\
\text { lebih baik dalam menutup } \\
\text { bunga. }\end{array}$ \\
\hline 3 & $\begin{array}{l}\text { Rifky Budi } \\
\text { Setiawan } \\
(2007)\end{array}$ & $\begin{array}{l}\text { Analisis } \text { Arus Kas } \\
\text { pada PT. Geoteknik } \\
\text { Indonesia }\end{array}$ & $\begin{array}{ll}\text { Independen: } & \text { Analisis } \\
\text { Arus Kas } & \\
\text { Dependen: } & \text { Kinerja } \\
\text { Keuangan } & \\
\text { Perusahaan } & \end{array}$ & $\begin{array}{l}\text { Dengan adanya analisis laporan } \\
\text { arus kas ini, PT Geoteknik } \\
\text { Indonesia dapat melihat } \\
\text { perbandingan dari persentase } \\
\text { kas dalam } 2 \text { tahun yaitu tahun } \\
2005 \text { dan } 2006 \text { sehingga dapat } \\
\text { diketahui pergerakan atau } \\
\text { perubahan dari komposisi kas } \\
\text { apakah mengalami kenaikan } \\
\text { atau penurunan. PT Geoteknik } \\
\text { Indonesia telah menggunakan } \\
\text { kasnya secara efisien mungkin } \\
\text { dimana tidak terjadi } \\
\text { penyimpangan - penyimpangan } \\
\text { penggunaan kas. }\end{array}$ \\
\hline
\end{tabular}

\section{HASIL DAN PEMBAHASAN}

\section{Analisis Laporan Arus Kas PT Kalbe Farma Tbk.}

Laporan arus kas merupakan salah satu objek analisis terhadap laporan keuangan, yang bisa digunakan untuk menilai kinerja suatu perusahaan. Salah satu analisis kinerja keuangan dengan menggunakan informasi laporan arus kas adalah analisis rasio laporan arus kas. Dalam analisis laporan arus kas ini objek penelitian yang digunakan adalah laporan arus kas PT Kalbe Farma Tbk, selama jangka waktu 5 (lima) tahun yaitu tahun 2008 sampai dengan tahun 2012.

Berikut ini adalah laporan arus kas PT Kalbe Farma Tbk. dalam kurun waktu selama 5 (lima) tahun yaitu tahun 2008 sampai dengan tahun 2012.

Tabel 4.1

PT. Kalbe Farma Tbk

Periode Tahun 2008-2012

(dalam satuan Rupiah)

\begin{tabular}{|c|c|c|c|c|c|c|}
\hline & $\begin{array}{c}\text { ARUS KAS DARI AKTIVITAS } \\
\text { OPERASI }\end{array}$ & 2008 & 2009 & 2010 & 2011 & 2012 \\
\hline- & Penerimaan Kas dari Pelanggan & 7.804.970.069.835 & 9.686 .123 .840 .950 & 11.039.919.268.228 & 11.692.691.590.575 & 14.721.985.301.073 \\
\hline- & $\begin{array}{l}\text { Pembayaran Kas kepada Pemasok dan } \\
\text { Karyawan }\end{array}$ & $(4.505 .841 .240 .394)$ & $(6.048 .673 .889 .076)$ & $(6.637 .307 .422 .355)$ & $(6.666 .419 .098 .277)$ & $(9.499 .733 .203 .632)$ \\
\hline \multicolumn{2}{|r|}{ Jumlah kas yang diperoleh dari Operasi } & 3.299.128.829.441 & 3.637.449.951.874 & 4.402.611.845.873 & 5.026.272.492.298 & 5.222.252.097.441 \\
\hline & $\begin{array}{c}\text { ARUS KAS DARI AKTIVITAS } \\
\text { OPERASI }\end{array}$ & 2008 & 2009 & 2010 & 2011 & 2012 \\
\hline - & $\begin{array}{l}\text { Penerimaan Tagihan Restitusi Pajak } \\
\text { Penghasilan }\end{array}$ & 8.049 .202 .297 & 12.928.224.377 & 20.723 .925 .034 & 5.468 .734 .764 & 20.838 .271 .516 \\
\hline- & $\begin{array}{l}\text { Pembayaran Biaya Iklan, Pameran dan } \\
\text { Promosi }\end{array}$ & $(1.063 .640 .714 .293)$ & - & 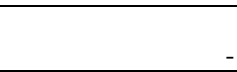 & $-x_{1}=x_{1}$ & \\
\hline
\end{tabular}




\begin{tabular}{|c|c|c|c|c|c|c|}
\hline- & Pembayaran Pajak Penghasilan & (356.142.206.993) & $(389.941 .951 .209)$ & $(435.230 .559 .227)$ & $(424.641 .078 .879)$ & (526.395.928.795) \\
\hline- & $\begin{array}{l}\text { Pembayaran untuk Beban Operasi } \\
\text { Lainnya, Bersih }\end{array}$ & $(1.079 .694 .575 .108)$ & $(1.896 .852 .784 .081)$ & $(2.734 .197 .347 .984)$ & (3.133.604.924.877) & (3.340.350.450.137) \\
\hline & $\begin{array}{l}\text { Kas Bersih Diperoleh dari Aktivitas } \\
\text { Operasi }\end{array}$ & 807.700.535.344 & 1.363.583.440.961 & 1.253.907.863.696 & 1.473.495.223.306 & 1.376.343.990.025 \\
\hline & $\begin{array}{c}\text { ARUS KAS DARI AKTIVITAS } \\
\text { INVESTASI }\end{array}$ & & & & & \\
\hline- & $\begin{array}{l}\text { Hasil Penjualan Investasi Jangka } \\
\text { Panjang }\end{array}$ & 460.518 .817 .622 & 149.516.929.663 & 115.049.212.900 & - & \\
\hline- & Penerimaan penghasilan Bunga & 56.492 .357 .164 & 66.981 .541 .962 & 54.977 .618 .234 & 99.743 .128 .114 & 74.469 .005 .621 \\
\hline- & $\begin{array}{l}\text { Hasil Penjualan Investasi jangka } \\
\text { Pendek }\end{array}$ & - & - & 52.000 .000 .000 & 125.000 .000 .000 & 145.968 .396 .881 \\
\hline- & Hasil Penjualan Aset Tetap & 10.172 .535 .153 & 20.331 .354 .930 & 19.642 .293 .246 & 22.069 .554 .517 & 24.409 .656 .786 \\
\hline- & Perolehan Aset Tetap & $(305.198 .137 .295)$ & $(277.596 .519 .508)$ & $(469.775 .003 .400)$ & (469.105.400.047) & (783.478.091.342) \\
\hline - & $\begin{array}{l}\text { Penempatan pada Investasi Jangka } \\
\text { Pendek dan Deposito Berjangka }\end{array}$ & (408.425.696.543) & $(84.443 .721 .852)$ & $(4.720 .275 .000)$ & $(233.555 .498 .181)$ & (270.905.474.717) \\
\hline- & Akuisisi Entitas Anak & - & & - & - & $(98.589 .277 .885)$ \\
\hline- & $\begin{array}{l}\text { Perolehan Saham Anak Perusahaan dari } \\
\text { Pihak Ketiga }\end{array}$ & - & $(522.124 .829 .650)$ & - & (172.978.048.157) & - \\
\hline - & $\begin{array}{l}\text { Penerimaan uang muka penjualan } \\
\text { investasi jangka panjang }\end{array}$ & - & 1.263 .900 .400 & - & - & - \\
\hline & $\begin{array}{l}\text { Penerimaan dari Aktivitas Investasi } \\
\text { Lainnya, Bersih }\end{array}$ & 215.179 .709 & 631.147 .163 & 692.346 .074 & $(2.127 .329 .364)$ & $(6.405 .934 .241)$ \\
\hline \multicolumn{2}{|r|}{$\begin{array}{c}\text { Kas Bersih Digunakan untuk Aktivitas } \\
\text { Investasi }\end{array}$} & $(186.224 .944 .190)$ & $(645.440 .196 .892)$ & (232.133.807.946) & $(630.953 .593 .118)$ & $(914.531 .718 .897)$ \\
\hline \multicolumn{7}{|c|}{$\begin{array}{c}\text { ARUS KAS DARI AKTIVITAS } \\
\text { PENDANAAN }\end{array}$} \\
\hline- & Penerimaan Hutang Bank & 292.853.342.945 & 2.432.741.994.739 & 676.112.994.004 & 579.500 .805 .283 & 261.182 .689 .814 \\
\hline- & $\begin{array}{l}\text { Penerimaan Setoran Modal Saham dari } \\
\text { Pemegang Saham Minoritas Anak } \\
\text { Perusahaan }\end{array}$ & 500.000 .000 & 1.036 .000 .000 & 11.984.202.801 & 49.721.581.911 & 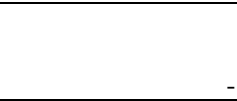 \\
\hline- & $\begin{array}{l}\text { Penerimaan dari Penjualan Kembali } \\
\text { Saham }\end{array}$ & - & & 3.121 .157 .136 & - & - \\
\hline- & $\begin{array}{l}\text { Penerimaan dari Aktivitas Pendanaan } \\
\text { lainnya, Bersih }\end{array}$ & - & & - & - & 1.208 .750 .000 \\
\hline - & Pembayaran Hutang Bank & $(190.681 .390 .174)$ & $(2.239 .498 .664 .386)$ & $(990.657 .002 .290)$ & $(463.734 .609 .433)$ & $(229.758 .630 .216)$ \\
\hline- & Pembayaran Obligasi & - & $(259.319 .000 .000)$ & - & - & - \\
\hline- & Pembayaran Dividen Kas Perusahaan & $(96.707 .694 .218)$ & $(117.234 .055 .275)$ & $(234.375 .610 .551)$ & $(549.527 .564 .394)$ & (890.627.320.090) \\
\hline- & $\begin{array}{l}\text { Pembayaran Dividen Kas Anak } \\
\text { Perusahaan }\end{array}$ & $(26.731 .845 .186)$ & $(34.511 .737 .170)$ & $(18.729 .940 .573)$ & $(7.934 .007 .020)$ & $(25.415 .768 .588)$ \\
\hline- & Pembayaran Beban Bunga & $(55.354 .893 .471)$ & $(48.150 .013 .121)$ & $(20.716 .334 .764)$ & $(14.586 .783 .377)$ & $(17.206 .912 .832)$ \\
\hline - & Pembayaran Dana Pensiun & - & & - & - & $(20.373 .200 .475)$ \\
\hline- & Pembelian Kembali Obligasi & $(9.851 .000 .000)$ & 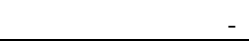 & - & - & \\
\hline - & Penarikan Kembali Saham Perusahaan & $(351.199 .458 .569)$ & (119.092.608.824) & - & - & \\
\hline
\end{tabular}

\begin{tabular}{|r|l|r|r|r|r|r|}
\hline \multicolumn{2}{|c|}{$\begin{array}{r}\text { ARUS KAS DARI AKTIVITAS } \\
\text { OPERASI }\end{array}$} & $\mathbf{2 0 0 8}$ & $\mathbf{2 0 0 9}$ & $\mathbf{2 0 1 0}$ & $\mathbf{2 0 1 1}$ & \\
\hline- & $\begin{array}{l}\text { Penarikan Kembali Saham Anak } \\
\text { Perusahaan }\end{array}$ & - & $(5.972 .262 .925)$ & $(1.215 .290 .983)$ & & - \\
\hline- & Pembayaran Hutang Sewa Pembiayaan & $(2.526 .845 .665)$ & $(741.355 .797)$ & $(192.221 .675)$ & $(414.715 .912)$ & $(278.225 .748)$ \\
\hline
\end{tabular}




\begin{tabular}{|c|c|c|c|c|c|c|}
\hline \multicolumn{2}{|r|}{$\begin{array}{l}\text { Kas Bersih digunakan untuk Aktivitas } \\
\text { Pendanaan }\end{array}$} & \multirow{2}{*}{$\begin{array}{r}\mathbf{( 4 3 9 . 6 9 9 . 7 8 4 . 3 3 8 )} \\
181.775 .806 .816 \\
\end{array}$} & \multirow{2}{*}{$\begin{array}{r}\mathbf{( 3 9 0 . 7 4 1 . 7 0 2 . 7 5 9 )} \\
380.008 .210 .597 \\
\end{array}$} & \multirow{2}{*}{$\begin{array}{r}\mathbf{( 5 7 4 . 6 6 8 . 0 4 6 . 8 9 5 )} \\
447.106 .008 .855 \\
\end{array}$} & \multirow{2}{*}{$\begin{array}{r}\mathbf{( 4 0 6 . 9 7 5 . 2 9 2 . 9 4 2 )} \\
435.566 .337 .246 \\
\end{array}$} & \multirow{2}{*}{$\begin{array}{l}\mathbf{( 9 2 1 . 2 6 8 . 6 1 8 . 1 3 5 )} \\
(459.456 .347 .007)\end{array}$} \\
\hline- & $\begin{array}{l}\text { Kenaikan (Penurunan)Bersih Kas dan } \\
\text { Setara Kas }\end{array}$ & & & & & \\
\hline- & $\begin{array}{l}\text { Pengaruh Bersih Perubahan Kurs pada } \\
\text { Kas dan Setara Kas yang Didenominasi } \\
\text { dalam Mata Uang Asing }\end{array}$ & 23.675 .684 .286 & $(86.958 .582 .016)$ & $(13.156 .493 .737)$ & $(39.181 .141 .451)$ & $(1.229 .379 .680)$ \\
\hline- & Kas dan Setara Kas Awal Tahun & 1.116.346.134.197 & 1.266.209.002.848 & 1.559.682.224.604 & 1.893.315.663.897 & 2.289.700.859.692 \\
\hline- & $\begin{array}{l}\text { Dikurang Saldo Akhir Periode kas dan } \\
\text { Setara Kas Milik PT Kageo Igar Jaya } \\
\text { Tbk. Dan Anak Perusahaan }\end{array}$ & - & - & $(100.316 .075 .825)$ & - & - \\
\hline & $\begin{array}{l}\text { Ditambah Saldo Awal Tahun Kas dan } \\
\text { Setara Kas Milik PT Pharma Metric } \\
\text { Labs. }\end{array}$ & - & 423.593 .175 & 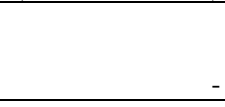 & & \\
\hline & Kas dan Setara Kas Akhir Tahun & 1.321.797.625.299 & 1.559.682.224.604 & 1.893.315.663.897 & 2.289 .700 .859 .692 & 1.829.015.133.005 \\
\hline
\end{tabular}

Dari tabel 4.1 diatas dapat diketahui bahwa laporan arus kas PT Kalbe Farma Tbk. menyajikan penerimaan dan pembayaran dari kas yang diklasifikasikan ke dalam aktivitas operasi, investasi dan pendanaan yang disajikan dengan metode langsung. Selama 5 (lima) tahun berturut turut saldo kas PT Kalbe Farma Tbk. mengalami surplus serta peningkatan yang signifikan khususnya pada tahun 2009 dan 2011. Surplus ini terjadi karena pada empat tahun terakhir tidak ada lagi pengeluaran perusahaan untuk pembayaran iklan, pameran dan promosi. Selain itu perusahaan juga mengalami kenaikan nilai pada penerimaan kas dari pelanggan tiap tahunnya.

Pada tahun 2008 kas dari aktivitas operasi berjumlah 807.700.535.344, pada tahun 2009 kas dari aktivitas operasi mengalami kenaikan yang cukup tinggi menjadi 1.363.583.440.961. Pada tahun 2010 kas dari aktivitas operasi berjumlah 1.253.907.863.696 dan mengalami kenaikan pada tahun 2011 sebesar 219.587.359.610 atau sekitar $18 \%$. Pada tahun 2012 kas operasi adalah sebesar 1.376.343.990.025 atau mengalami penurunan sebesar
97.151.233.281 jika dibandingkan dengan tahun 2011.

\section{Analisis Rasio Arus Kas PT Kalbe Farma Tbk.}

Semakin banyaknya perusahaan yang mencantumkan laporan arus kas dalam laporan keuangan tahunan, membuat pengguna informasi menjadikan laporan arus kas sebagai alat analisis kinerja perusahaan semakin meningkat. Salah satu analisis kinerja keuangan dengan menggunakan laporan arus kas adalah analisis rasio laporan arus kas. Analisis laporan arus kas ini menggunakan beberapa komponen dari laporan posisi keuangan (neraca) dan laporan laba rugi sebagai alat analisis rasio.

Kinerja keuangan dapat dikatakan sebagai hasil yang dicapai oleh perusahaan atas berbagai aktivitas yang dilakukan dalam mendayagunakan sumber keuangan yang tersedia. Dalam penelitian ini kinerja keuangan diukur dari laporan arus kas PT Kalbe Farma Tbk. selama 5 (lima) tahun yaitu tahun 2008 sampai dengan tahun 2012.

Berikut penulis sajikan tabel 4.10 mengenai hasil perhitungan rasio rasio arus kas selama 5 (lima) tahun 
Tabel 4.2

Rasio-Rasio Arus Kas PT. Kalbe Farma Tbk

Tahun 2008-2012

\begin{tabular}{|c|c|c|c|c|c|c|}
\hline No. & RASIO ARUS KAS & 2008 & 2009 & 2010 & 2011 & 2012 \\
\hline 1 & Rasio Arus Kas Operasi (AKO) & $0,65 \%$ & $0,87 \%$ & $1,09 \%$ & $0,90 \%$ & $0,73 \%$ \\
\hline 2 & Rasio Cakupan Arus Dana (CAD) & 3,77 Kali & 4,19 Kali & 4,33 Kali & 4,30 Kali & 4,37 Kali \\
\hline 3 & Rasio Cakupan Kas terhadap Bunga (CKB) & 10,15 Kali & 21,26 Kali & 65,02 Kali & 436,86 Kali & 178,91 kali \\
\hline 4 & Rasio Cakupan Kas terhadap Hutang Lancar (CKHL) & 0,56 Kali & 0,79 Kali & 0,86 Kali & 0,46 Kali & 0,20 Kali \\
\hline 5 & Rasio Pengeluaran Modal (PM) & 2,65 Kali & 4,91 Kali & 2,67 Kali & 3,14 Kali & 1,76 Kali \\
\hline 6 & Rasio Total Hutang (TH) & $0,59 \%$ & $0,81 \%$ & $0,99 \%$ & $0,84 \%$ & $0,67 \%$ \\
\hline 7 & Rasio Arus Kas Bersih Bebas (AKBB) & $18,38 \%$ & $19,92 \%$ & $25,44 \%$ & $25,96 \%$ & $25,85 \%$ \\
\hline 8 & Rasio Kecukupan Arus Kas (KAK) & 1,17 Kali & 1,46 Kali & 1,79 Kali & 1,92 Kali & 2,41 Kali \\
\hline
\end{tabular}

Sumber : Data yang diolah, 2014

Dari tabel 4.10 diatas dapat diketahui bahwa rasio arus kas operasi tahun 2008 sampai dengan tahun 2012 menunjukkan pencapaian kurang dari 1 sehingga kemungkinan perusahaan tidak mampu membayar kewajiban lancarnya melalui kas dari aktivitas operasi saja. Namun, pada tahun 2010 nilai rasio menunjukkan angka diatas satu, sehingga perusahaan dianggap mampu membayar kewajiban lancarnya melalui kas dari aktivitas operasi saja.

Untuk rasio cakupan arus dana selama 5 tahun berturut turut (2008 2012) terlihat bahwa terjadi perbaikan dan peningkatan rasio cakupan dana dari tahun ke tahun seperti terlihat pada tahun 2009 sampai dengan tahun 2012, yang berarti laba sebelum pajak PT Kalbe Farma Tbk. mengalami peningkatan yang cukup baik dan dibarengi dengan tingginya jumlah hutang pajak.

Rasio cakupan arus kas terhadap bunga selama lima tahun berturut turut
(2008-2012) mengalami kenaikan terutama pada tahun 2011, namun terjadi penurunan pada tahun 2012 . Meskipun demikian, nilai rasio pada tahun 2012 masih melebihi nilai rasio pada 3 tahun pertama. Besarnya nilai rasio ini memberi artian bahwa kemampuan arus kas operasi dalam menutup biaya bunga perusahaan mengalami peningkatan khususnya pada tahun tahun terakhir yaitu tahun 2011.

Untuk rasio cakupan kas terhadap hutang lancar dalam rentang 5 tahun ini (2008 - 2012) PT Kalbe FarmaTbk. menunjukkan kemampuan arus kas operasi yang rendah dalam menutupi hutang lancarnya, dan dari rasio - rasio yang dihasilkan terlihat adanya penurunan nilai khususnya pada tahun 2011 dan tahun 2012 karena tingginya nilai hutang lancar yang tidak seimbang dengan kenaikan arus kas operasi dan dividen kas. Akan tetapi pada tahun 2010, rasio cakupan kas terhadap 
hutang lancar mengalami kenaikan dibandingkan dengan tahun 2009, akan tetapi jika dibandingkan dengan nilai rasio tahun 2008 nilai rasio cakupan kas terhadap hutang lancar jauh lebih baik, hal ini dikarenakan turunnya nilai hutang lancar pada tahun 2009 tersebut. Nilai rasio yang rendah tentu saja memunculkan kemungkinan perusahaan akan mengalami kesulitan dalam menutupi kewajiban lancarnya.

Rasio pengeluaran modal selama lima tahun (2008 - 2012) diatas juga menunjukkan angka rasio yang rendah sehingga kemungkinan perusahaan mengalami kesulitan dalam membiayai pengeluaran modalnya melalui arus kas operasi saja. Akan tetapi pada tahun 2011, nilai arus kas operasi meningkat sehingga rasio pengeluaran modal pada tahun ini ikut meningkat. Hal ini menyatakan bahwa perusahaan mampu membiayai pengeluaran modal perusahaannya. Karena rasio yang tinggi menunjukkan kemampuan yang tinggi dari arus kas dalam membiayai pengeluaran modal.

Dan dari hasil rasio pada tabel 4.10 diatas juga terlihat bahwa perusahaan memiliki kemampuan yang rendah dalam membayar total hutangnya melalui arus kas operasi bersih perusahaan, sehingga perusahaan harus memiliki sumber arus kas selain arus kas normal perusahaan untuk menutupi total hutangnya.

Sedangkan rasio arus kas bersih bebas selama 5 tahun yaitu tahun 2008 sampai dengan tahun 2012 cenderung berfluktuatif dan mengalami peningkatan yang signifikan dari tahun ke tahun. Hal ini disebabkan karena adanya kenaikan pada nilai laba bersih dan meningkatnya nilai pengeluaran modal serta hutang jangka panjang.

Hasil perhitungan untuk rasio kecukupan arus kas, PT Kalbe Farma Tbk. menunjukkan kecukupan arus kas yang memadai untuk jangka waktu 5 tahun kedepan. Meningkatnya nilai rasio setiap tahunnya menunjukkan bahwa meningkatnya laba perusahaan. Hal ini dibuktikan dengan naiknya nilai laba usaha setiap tahunnya.

Dari tabel 4.10 di atas dapat ditarik kesimpulan bahwa kinerja perusahaan selama 5 (lima) tahun yaitu tahun 2008 sampai dengan tahun 2012 yang diukur dari rasio laporan arus kas adalah kurang baik. Hal ini bisa dilihat dari nilai rasio yang dihasilkan dari masing masing rasio - rasio arus kas di atas. Dari tahun 2008 sampai 2012 rata - rata rasio yang dihasilkan cenderung mengalami peningkatan. Hanya saja ada beberapa rasio yang mengalami penurunan, namun rasio tertinggi terjadi pada tahun 2011 yang ditandai dengan tingginya nilai rasio dari masing masing rasio - rasio di atas.

\section{SIMPULAN DAN IMPLIKASI PENELITIAN}

Dari hasil penelititan dan pembahasan yang dilakukan oleh penulis mengenai analisis laporan arus kas untuk mengukur kinerja keuangan pada PT Kalbe Farma Tbk. selama 5 (lima) tahun yaitu tahun 2008 sampai dengan tahun 2012, maka penulis memberikan kesimpulan sebagai berikut:

1) Hasil analisa arus kas periode tahun 2008 - 2012, dengan menggunakan rasio arus kas operasi menunjukkan rasio yang rendah yaitu 0,$65 ; 0,87 ; 1,09 ; 0,90$ dan 0,73 . Pada 2 tahun terakhir tidak ada yang melebihi dari 1 sehingga disimpulkan kemungkinan PT. Kalbe Farma Tbk. tidak mampu membayar kewajiban lancarnya melalui arus kas dari aktivitas operasi saja. 
2) Kemampuan laba sebelum pajak dalam menutup komitmen komitmen perusahaan yang akan jatuh tempo periode tahun 2008 sampai dengan tahun 2012 masing - masingnya adalah sebagai berikut: 3 kali, 4 kali, 4 kali, 4 kali dan 4 kali. Dari rasiorasio cakupan arus dana yang dihasilkan pada tahun 2008 2012 rata - rata pada kisaran rasio yang sama dan hanya mengalami sedikit peningkatan tiap tahunnya.

3) Kemampuan arus kas operasi dalam menutup biaya bunga perusahaan periode tahun 2008 2012 masing - masingnya sebagai berikut: 10 kali, 21 kali, 65 kali, 436 kali dan 178 kali. Rasio diatas menunjukkan bahwa terjadi peningkatan tiap tahunnya kecuali pada tahun 2012, pada tahun 2012 kembali mengalami penurunan nilai rasio dari tahun sebelumnya. Meskipun demikian kemampuan arus kas operasi dalam menutup biaya bunga perusahaan mengalami peningkatan khususnya pada tahun 2011 dan itu berarti perusahaan mampu menutup biaya bunga perusahaan dengan arus kas operasi perusahaannya.

4) Kemampuan arus kas operasi dalam membayar hutang lancar perusahaan periode tahun 2008 2012 masing - masingnya sebagai berikut : 0,$56 ; 0,79 ; 0,86 ; 0,46$ dan 0,20 sehingga terlihat bahwa rata - rata kemampuan perusahaan dalam membayar hutang lancarnya melalui arus kas dari aktivitas operasi mengalami penurunan tiap tahunnya, namun pada tahun 2010 nilai rasio cakupan kas terhadap hutang lancar perusahaan lebih tinggi dan kemungkinan perusahaan tidak akan mengalami kesulitan dalam menutupi hutang lancarnya pada tahun tersebut. Untuk tahun 2011 dan tahun 2012 kemungkinan perusahaan akan mengalami sedikit kesulitan dalam menutupi hutang lancarnya melalui kas dari aktivitas operasi.

5) Rasio Pengeluaran Modal untuk tahun 2008-2012 adalah 2,65; 4,$91 ; 2,67 ; 3,14$ dan 1,76 yang berarti kemampuan perusahaan dalam membiayai pengeluaran modalnya dari arus kas aktivitas operasi cenderung berfluktuatif dari tahun ke tahun, namun terjadi penurunan pada tahun 2012 sehingga diperlukan alternatif pembiayaan dari sumber lainnya.

6) Total hutang perusahaan yang dijamin dengan arus kas operasi bersih adalah sebesar $0,59 \%$ pada tahun $2008,0,81 \%$ pada tahun 2009 sedangkan untuk tahun 2010 dan 2011 masing masingnya sebesar $0,99 \%$ dan $0,84 \%$, dan untuk tahun 2012 sebesar $0,67 \%$, Perusahaan memiliki kemampuan yang rendah dalam membayar total hutangnya melalui arus kas operasi bersih perusahaan, sehingga perusahaan harus memiliki sumber arus kas selain arus kas normal perusahaan untuk menutupi total hutangnya.

7) Rasio arus kas bersih yang bebas periode tahun 2008 - 2012 masing masingnya adalah $18,38 \% ; 19,92 \% ; 25,44 \% ; 25,96$ dan $25,85 \%$. Terlihat rasio arus kas yang berfluktuatif dan mengalami kenaikan yang cukup signifikan di setiap tahunnya.

8) Rasio kecukupan arus kas tahun 2008 sampai dengan tahun 2012 
terus mengalami peningkatan, yaitu 1,17 kali; 1,46 kali; 1,79 kali; 1,92 kali dan 2,41 kali, peningkatan nilai rasio ini menyatakan bahwa perusahaan mampu menjamin penyediaan kas perusahaannya untuk memenuhi kewajibannya dalam jangka waktu 5 tahun mendatang.

9) Berdasarkan laporan arus kas perusahaan, pola aliran kas yang terjadi pada PT Kalbe Farma Tbk. adalah arus kas dari aktivitas operasi dan pendanaan bernilai positif, sedangkan arus kas dari aktivitas investasi bernilai negatif berarti perusahaan menggunakan kas dari operasional dan pinjaman/penarikan modal untuk melakukan investasi.

10) Penelitian ini jika dibandingkan dengan penelitian terdahulu cenderung sama. Hal ini dapat terlihat dari pola aliran kas yang terjadi pada perusahaan yang dijadikan objek penelitian. Pola arus kas yang berasal dari aktivitas operasi dan pendanaan bernilai positf, sedangkan arus kas dari aktivitas investasi bernilai negatif sehingga perusahaan menggunakan kas dari operasional dan pinjaman/penarikan modal untuk melakukan investasi.

Dari semua kesimpulan diatas dapat dilihat bahwa kinerja keuangan PT. Kalbe Farma Tbk. khususnya dari analisis laporan arus kas periode tahun 2008 - 2012 adalah kurang baik. Hal ini bisa dilihat dari nilai rasio yang dihasilkan dari masing - masing rasio rasio arus kas di atas. Dari tahun 2008 sampai 2012 rata - rata rasio yang dihasilkan cenderung rendah dan mengalami penurunan tiap tahunnya. Implikasi penelitian diharapkan dapat memberikan kontribusi keilmuan kepada shakeholder variabel dari penelitian ini.

\section{DAFTAR PUSTAKA}

Ananda, F., Putra, R. D. and Hendrastyo, V. S. (2017) 'Kesuksesan Implementasi System Application Product (SAP) studi kasus di PT. Semen Padang', Jurnal Pundi, 1(1), pp. 1-10. doi: 10.31575/jp.v1i1.4.

Ananda, F. and Zulvia, D. (2018) 'Indikasi machiavellianism dalam pembuatan keputusan etis auditor pemula', Benefita, 3(September), pp. 357-369. doi: 10.22216/jbe.v3i3.3660.

Arief Habib, (2008), Kiat Jitu Peramalan Saham, Andi, Jogjakarta.

Darsono dan Ashari, (2005), Pedoman Praktis Memahami Laporan Keuangan,

Andi, Yogyakarta.

Dery Alfian Lutfi, (2013), Manfaat Analisis Rasio laporan Keuangan Untuk Menilai Kinerja Keuangan Perusahaan Pada Kelompok Industri Logam Mineral lainnya, Universitas Widyatama, Bandung.

Dwi Prastowo dan Rifka Julianty, (2002), Analisis Laporan Keuangan, AMP YKPN, Yokyakarta.

Hengky Setiawan, (2006), Analisis Rasio Arus kas Pada Perusahaan Kelompok Industri 
Semen, Universitas Widyatama, Bandung.

Ikatan Akuntansi Indonesia, (2002), Pernyataaan Standar Akuntansi Keuangan. PSAK No.1: Penyajian Laporan Keuangan, IAI, Jakarta.

Ikatan Akuntansi Indonesia, (2009), Pernyataaan Standar Akuntansi Keuangan. PSAK No.1 (Revisi 2009): Penyajian Laporan Keuangan, IAI, Jakarta.

Ikatan Akuntansi Indonesia, (2009), Pernyataaan Standar Akuntansi Keuangan. PSAK No.2 (Revisi 2009): Laporan Arus Kas, IAI, Jakarta.

Kieso, Donald E, Weygandt, Jery J, (2002), Akuntansi Intermediate, Edisi Ketujuh. Jilid Ketiga, Alih Bahasa
Herman Wibowo, Binapura Aksara, Jakarta.

Mulyadi, (2001), Akuntansi Manajemen: Konsep, Manfaat dan Rekayasa, Edisi Revisi, Bagian Penerbit Universitas Gajah Mada, Yogyakarta.

Munawir, (2004), Analisa Laporan Keuangan, Edisi Revisi, Liberty, Yogyakarta.

Rifky Budi Setiawan, (2007), Analisis Arus Kas pada PT. Geoteknik Indonesia, Universitas Sumatera Utara, Medan.

Soemarso,SR, (2010), Akuntansi Suatu Pengantar, Edisi Revisi, PT. Salemba Empat, Jakarta.

Sofyan Syafri Harahap, (2007), Analisis Kritis Atas Laporan Keuangan, PT Raja Grafindo Persada, Jakarta. 